\title{
Balance assessment of material and energy biosphere flows and the energy industry in an industrial region
}

\author{
Dmitry Dvinin ${ }^{1, *}$ and Aleksey Davankov ${ }^{1,2}$ \\ ${ }^{1}$ Chelyabinsk State University, 129, Kashirin Brothers Street, 454001, Chelyabinsk, Russia \\ ${ }^{2}$ Institute of Economics of the Ural Branch of the Russian Academy of Sciences, 29, Moskovskaya \\ Street, 620014, Yekaterinburg, Russia
}

\begin{abstract}
The balance assessment of biosphere material and energy flows and those resulting from economic activity in the industrial region is carried out. The analysis is based on the use of stability indicators of the region's socio-ecological and economic system. For balance assessment of material and energy biosphere flows and economic activity, the total material input criterion was used, where the consumed natural resources are reduced to a single value. It was found that the functioning of the energy sector operating on fossil fuels created significant imbalances in the material and energy flows. The balance indicator is calculated for the regions of the Ural Federal District. In all regions of the Ural Federal District, except for the YamalNenets Autonomous Area, the balance indicator is higher than the presence of general instability. The study allowed determining the magnitude of the ecological and economic effect in developing promising renewable energy sources. In 2 regions of the Ural Federal District, the scenario of replacing traditional energy with renewable energy will reduce the material intensity, which means that it will increase the level of balance of material and energy flows by more than 10 times.
\end{abstract}

\section{Introduction}

When assessing the balance of material and energy flows arising from economic activity, there is always some uncertainty caused by the need to use particular criteria. The activity of energy facilities leads not only to the formation of emissions into the environment but also to output flows, which are given the main attention when solving environmental issues, and creates input material and energy flows of consumed raw materials and energy. The use of natural resources in production activities and the movement of significant volumes of material substances in this process are more significant factors of a negative anthropogenic impact than traditional emissions and discharges [1,2]. As a result of such activities, ecosystems are deprived of some critical functions and can no longer provide the necessary living conditions. The level of withdrawal of natural resources from the biosphere as the socio-ecological-economic system grows over time and has an increasingly significant negative impact on global processes in living and non-living nature [3]. The regulation of

*Corresponding author: ecologchel@74.ru 
these processes requires a management model ensuring a balanced state of the region's social, ecological, and economic system within biosphere sustainability limits. In the 1990s, Gorshkov's theory of biotic regulation was developed in Russia, arguing that going beyond the biosphere stability, and consequently the emergence of environmental problems, is caused by the socio-economic system switching to the material and energy flows of the biosphere [4]. Therefore, the analysis of the material and energy intensity of the primary economic sectors has an environmental aspect and is also a significant factor for determining the industrial region's further economic competitiveness.

\section{Materials and methods}

All evolving systems are open. As a particular case of an open self-developing system, the socio-ecological and economic system must obey the general development laws of arbitrary open systems. Significantly more complex systems must have mechanisms for the formation of stable material and energy flows. A social production model considers the relationship between nature and society proposed by Kuznetsov. This model is an extension of the intersectoral balance by including natural reserves of raw materials, energy and labor resources, and corresponding flows. The social production model of Kuznetsov is conceptual and shows what tasks need to be learned to solve if organizing sustainable links between society and nature. Thus, the regional socio-ecological and economic environment consists of three major subsystems: changes in matter, changes in energy, and a management subsystem responsible for transforming information flows. It is necessary to influence the management subsystem to manage the economic activity of the regional socio-ecological and economic environment within the boundaries of the biosphere stability; information flows must set the necessary proportions of the distribution of energy and matter flows in the other two subsystems. Accordingly, the management mechanism should be based on the use of sustainability indicators of the socio-ecological and economic system, where there is a common indicator of the economic capacity of the regional ecosystem [5].

According to the proposed methodology, the ecosystem economic capacity should be estimated by the maximum permissible energy load, namely the ability of landscapes in a particular territory to emit a certain amount of oxygen and simultaneously absorb carbon dioxide, which has a greenhouse effect and directly indicates the level of development of regional energy, and therefore nature-intensive economic activity [4]. In this case, such an indicator as the volume of total energy consumption in the region and the characteristics of the landscapes of the studied territory will be important: forested area, the presence of areas free of forests, agricultural land, various water bodies.

The total indicator of the regional economic capacity $(\mathrm{Ne})$ must be determined according to the following formula:

$$
N_{e}=N \sum_{i=1}^{6} \frac{S_{i}^{e}}{S_{i}} p_{i}
$$

where $\mathrm{N}$ - total economic capacity of the biosphere (1.5 TW), S1 - total area of deciduous forests, S2 - total area of coniferous forests, S3 - other forest areas, S4 - non-forest area, S5 - agricultural land, $\mathrm{S} 6$ - water bodies, $\mathrm{Si}^{\mathrm{e}}$ - ratio to the $\mathrm{Si}$ area of the studied region, $\mathrm{pi}$ contribution ratio of the $i$-th indicator in waste assimilation.

The overall region assessment in dynamics, from the development of positive or negative processes, should be carried out based on the stability indicator of the regional system. The impact in the course of management activities allows changing the situation, forming a balanced regional development. The ratio level of energy consumed in any territory to the 
indicator of the regional economic capacity is of great importance to assess the process dynamics:

$$
K_{\text {Sust.. }}^{t}=\frac{E^{t}}{N_{e}} \text {, }
$$

where $E^{t}$ - total amount of energy consumed in the region for a certain period.

If $K^{t}$ Sust . is less than one, the region's development can be considered relatively stable; if more, it is an unstable state. The global average value of this ratio is about 10 . Hence, the authors can conclude that if this indicator has values greater than 10 , the region has a negative impact on the state of the global stability of ecosystems.

It is necessary to apply a single criterion that allows assessing the consumption of various natural resources, the movement of ecosystem elements, in some cases without a market price to carry out such an analysis of the material intensity of the economy [6, 7]. For individual energy companies, an indicator of the specific material intensity of a product or service obtained from the MIPS (Material Input Per Service unit) method can be used. This method allows analyzing the "input" material flows resulting from production activities; its basis is the criterion of MI (material input) numbers [8]. This criterion allows evaluating the total material input of products per unit of product or service received. They often express the total amount of natural resources used (in kilograms or tons) required to produce one kilogram of the main product. MI numbers calculated for all primary raw materials and semi-finished products are available on the website of the Wuppertal Institute for Climate and Environment (Germany) www.wupperinst.org. Using the data obtained by the Institute, the MI numbers of any other complex products and services can be calculated. It is proposed to use the criterion of total MI numbers without allocating separate categories of "material input" to assess the balance of material and energy biosphere flows and the energy of economic activity. All consumed natural resources are reduced to a single value, which allows for further effective environmental and economic assessment. Since the total MI numbers express the total "material input," they can also be used to analyze the material intensity of the regional socio-ecological and economic system. In analyzing the total MI numbers of electric power facilities, it is possible to identify the dependence that exists between the level of consumption of natural resources and greenhouse gas emissions, which allows planning to reduce their emissions through the implementation of resource-saving mechanisms [9].

\section{Results}

Using the example of electricity production, a study was conducted that revealed that significant material intensity values were present in the industrial regions of the Ural Federal District with large coal-fired power plants. They have a significant negative anthropogenic impact, which is confirmed by the significant amount of greenhouse gas emissions. Table 1 shows the regions with the traditional electric power industry with the highest material intensity (more than $1 \mathrm{~kg} / \mathrm{kWh}$ ). 
Table 1. Regions of the Ural Federal District of Russia with the highest specific material flows arising in the course of traditional energy activities.

\begin{tabular}{|c|c|c|}
\hline Region & $\begin{array}{c}\text { Total MI numbers of the } \\
\text { traditional electric power } \\
\text { industry, } \mathbf{~ k g} / \mathbf{k W h}\end{array}$ & $\begin{array}{c}\text { Specific greenhouse } \\
\text { gas emissions, } \\
\mathbf{~ k g} / \mathbf{k W h}\end{array}$ \\
\hline Kurgan Region & 1.32 & 0.58 \\
\hline Sverdlovsk Region & 1.64 & 0.76 \\
\hline Tyumen Region & 1.22 & 0.49 \\
\hline Khanty-Mansi Autonomous Area & 1.18 & 0.49 \\
\hline Chelyabinsk Region & 1.81 & 0.87 \\
\hline
\end{tabular}

Thus, traditional energy based on fossil fuels creates significant imbalances in material and energy flows.

According to the above methodology, the balance indicator was calculated for the Ural Federal District regions. The results are presented in Table 2.

Table 2. Regional balance development assessment of the Ural Federal District.

\begin{tabular}{|l|c|c|c|}
\hline \multicolumn{1}{|c|}{ Region } & $\begin{array}{c}\text { Ecological capacity } \\
\text { of ecosystems, GW }\end{array}$ & $\begin{array}{c}\text { Energy consumption per } \\
\text { unit of time (power } \\
\text { consumption), GW }\end{array}$ & $\begin{array}{c}\text { Regional } \\
\text { balance } \\
\text { indicator }\end{array}$ \\
\hline Sverdlovsk Region & 5.64 & 14.35 & 2.54 \\
\hline Chelyabinsk Region & 0.94 & 14.17 & 15.02 \\
\hline Kurgan Region & 0.67 & 1.70 & 2.56 \\
\hline Tyumen Region Autonomous & 2.39 & 4.81 & 2.01 \\
\hline $\begin{array}{l}\text { Khanty-Mansi Autonomous } \\
\text { Area }\end{array}$ & 14.05 & 22.16 & 1.58 \\
\hline $\begin{array}{l}\text { Yamal-Nenets } \\
\text { Area }\end{array}$ & 10.28 & 5.25 & 0.51 \\
\hline Ural Federal District & 33.94 & 62.46 & 1.84 \\
\hline
\end{tabular}

In all regions of the Ural Federal District, except for the Yamal-Nenets Autonomous Area, the balance indicator is higher than one, indicating general instability. An exceptionally high level of imbalance is found in the Chelyabinsk Region, more than 15, which is significantly higher than the global value of approximately 10 .

This indicator should also manifest itself in the level of material flows, which may indicate a significant impact on the environment. A comparative analysis of data on the specific resource intensity of the electric power industry with the balance indicator and the value of greenhouse gas emissions was carried out, which is presented in Table 3.

Table 3. Specific resource intensity and greenhouse gas emissions of the electric power industry in comparison with the sustainability indicator of the regions of the Ural Federal District.

\begin{tabular}{|l|c|c|c|}
\hline \multicolumn{1}{|c|}{ Region } & $\begin{array}{c}\text { Regional } \\
\text { balance } \\
\text { indicator }\end{array}$ & $\begin{array}{c}\text { Specific resource } \\
\text { intensity of the electric } \\
\text { power industry in } \\
\text { total } \mathbf{M I} \text { numbers, } \\
\mathbf{k g} / \mathbf{k W h}\end{array}$ & $\begin{array}{c}\text { Specific } \mathbf{C O}_{2} \\
\text { emissions-eq., } \\
\mathbf{k g} / \mathbf{k W h}\end{array}$ \\
\hline Sverdlovsk Region & 2.54 & 1.64 & 0.76 \\
\hline Chelyabinsk Region & 15.02 & 1.81 & 0.87 \\
\hline Kurgan Region & 2.56 & 1.32 & 0.58 \\
\hline
\end{tabular}




\begin{tabular}{|l|c|c|c|}
\hline Tyumen Region & 2.01 & 1.22 & 0.49 \\
\hline $\begin{array}{l}\text { Khanty-Mansi Autonomous } \\
\text { Area }\end{array}$ & 1.58 & 1.18 & 0.49 \\
\hline $\begin{array}{l}\text { Yamal-Nenets Autonomous } \\
\text { Area }\end{array}$ & 0.51 & 0.83 & 0.48 \\
\hline Ural Federal District & 1.84 & 1.33 & 0.57 \\
\hline
\end{tabular}

There is a high correlation between the regional balance indicator and the material flows of the electric power industry: the correlation ratio is 0.745 , and the specified ratio is 0.998 between the material flows and greenhouse gases. As a result, it is necessary to draw the following conclusion: if there is a high level of regional imbalance, there are also significant material flows in the electric power industry, high greenhouse gas emissions.

Recently, renewable energy has been widely developed; its peculiarity is that it uses energy already circulating in the biosphere, i.e., unlike traditional energy, it does not significantly affect the change in natural material and energy flows [10]. This suggests that its activities allow identifying new patterns associated with an increase in the level of balanced development of economic activity and the region's assimilation potential with an increase in the share of renewable energy in its energy balance. As the share of renewable energy in the energy balance increases, the balance of economic activity of the regional socioecological and economic system will also change.

Currently, the share of renewable energy in the total energy balance of the Russian Federation is $0.14 \%$ (excluding large hydroelectric power plants). The Russian renewable energy structure is as follows: small hydroelectric power plants and installations based on biofuels $-53.5 \%$, solar energy $-26 \%$, geothermal plants $-11 \%$, wind power installations $9.5 \%$. At the same time, it should be noted that the situation differs significantly for different regions of the country. In most of them, renewable energy sources are either not represented or have extremely insignificant values. In the absence of economic incentive mechanisms, renewable energy is perceived not as an opportunity to reduce the negative impact on the environment but as a way to provide electricity to remote areas.

In 2016, the National Research University Higher School of Economics implemented the project "Research on global challenges and long-term trends in innovative development," which presented four scenarios for developing renewable energy in Russia for the period up to 2030 .

Based on the expert assessment, a list of existing trends in renewable energy was formed. There are three renewable energy sources that have the most significant potential for development: wind power plants, solar power plants, and biomass-based fuels. Next, four development scenarios were formed, which received the following conditional names: "New energy structure," "Reliance on the hydrocarbon export," "The worst forecast comes true," and "Centralized diversification." Scenarios allowed obtaining the following output: macroeconomic indicators of economic growth for the foreseeable future will remain relatively small, which does not make optimistic about the rapid development of renewable energy. The most likely scenarios should be considered with the share of renewable sources $3-5 \%$ by 2030 .

The study determined what ecological and economic effect was expected when developing promising renewable energy sources in the Ural Federal District regions with the highest specific material flows of traditional energy.

The average specific value of material input for renewable energy in the Russian Federation is $0.15 \mathrm{~kg} / \mathrm{kWh}$ (in total MI numbers). This is the basis for comparison with traditional energy. Table 4 shows how much the specific material intensity will decrease if conventional energy is entirely replaced with renewable energy. 
Table 4. Regions of the Ural Federal District of Russia where the development of renewable energy can significantly affect the balance of material and energy flows.

\begin{tabular}{|c|c|}
\hline Regions & $\begin{array}{c}\text { What fold decrease in the specific material } \\
\text { input will be provided if conventional energy is } \\
\text { completely replaced with renewable energy }\end{array}$ \\
\hline Kurgan Region & 8.8 \\
\hline Sverdlovsk Region & 10.93 \\
\hline Tyumen Region & 8.13 \\
\hline Khanty-Mansi Autonomous Area & 7.87 \\
\hline Chelyabinsk Region & 12.07 \\
\hline
\end{tabular}

In 2 regions of the Ural Federal District, the scenario of replacing traditional energy with renewable energy will reduce the material intensity (and thus increase the overall level of balance of material and energy flows) by more than 10 times. Obviously, in the implementation of the scenario when renewable energy will make up 3-5\% of the energy balance, there is no significant change in the level of balance of material and energy flows. Thus, it is necessary to conclude that the balance of material and energy biosphere flows and the energy industry can be achieved only under much more ambitious scenarios for the transition to renewable energy sources.

\section{Conclusions}

The most promising renewable energy sources from an ecological and economic point of view, capable of effectively reducing the intensity of anthropogenic impact with insignificant values of specific material intensity, are primarily wind and solar energy sources. Thus, when replacing energy with fossil fuels, it is possible not only to solve energy problems in remote regions due to a lack of infrastructure but also to significantly increase the balance of material and energy flows resulting from economic activities in the territories of industrially developed regions.

In 2 regions of the Ural Federal District Russia, a hypothetical scenario of replacing traditional energy with renewable energy can reduce the material intensity of the industry and, therefore, increase the balance of material and energy flows by more than 10 times. The most significant ecological and economic effect will be shown in the following regions: Sverdlovsk Region (10.93 times), Chelyabinsk Region (12.07 times). However, this effect will manifest itself only if there is a large-scale transition to renewable energy use.

\section{Acknowledgement}

The reported study was funded by RFBR, project number 20-010-00195.

\section{References}

1. G. Huppes, M. Ishikawa, Ecological Economics 68, 1687-1700 (2009) DOI: 10.1016/j.ecolecon.2009.01.007

2. S. Salaa, B. Ciuffob, P. Nijkamp, Ecological Economics 119, 314-325 (2015) DOI: 10.1016/j.ecolecon.2015.09.015

3. S. Sangwon, Ecological Modelling 189, 251-269 (2005) DOI: 10.1016/j.ecolmodel.2006.01.002 
4. A.Y. Davankov, D.Y. Dvinin, Y.A. Postnikov, Economy of Region 4, 1029-1039 (2016) DOI: $10.17059 / 2016-4-5$

5. I.S. Belik, N.V. Starodubec, A.I. Yachmeneva, Economy of Region 4, 1211-1219 (2017) DOI: $10.17059 / 2017-4-19$

6. S. Giljum, Resources, Conservation and Recycling 55, 300-308 (2011) DOI: 10.1016/j.resconrec.2010.09.009

7. J. Korhonen, A. Honkasalo, J. Seppala, Ecological Economics 143, 37-46 (2018) DOI: 10.1016/j.ecolecon.2017.06.041

8. M. Ritthoff, H. Rohn, C. Liedtke, Calculating MIPS-Resource Productivity of Products and Services (Wuppertal Institute for Climate, Environment and Energy, Wuppertal, Germany, 2002) DOI: 10.3390/resources2040581

9. D.Y. Dvinin, E. Nikolaeva, E3S Web of Conferences 157, 03015 (2020) DOI: 10.1051/e3sconf/202015703015

10. H. Keiko, M. Takanori, H. Takashi, F. Ken-ichi, M. Takashi, Renewable Energy 93, 548-561 (2016) DOI: 10.1016/j.renene.2016.02.051 